\title{
CINTA TANAH AIR DI ERA GLOBAL
}

\section{LOVE FOR THE HOMELAND IN THE GLOBAL ERA}

\section{Yoachim Agus Tridiatno*, Chatarina Suryanti}

Universitas Atma Jaya Yogyakarta

Jalan Babarsari Nomor 44 Yogyakarta 55281, Indonesia

\section{INFO ARTIKEL}

\section{Riwayat Artikel:}

Diterima : 27 Mei 2021

Disetujui : 12 Desember 2021

\section{Keywords:}

urgency, education, love for the homeland, global era

\section{Kata Kunci:}

urgensi, pendidikan, cinta tanah air, era global

\section{*) Korespondensi:}

E-mail: tridiatno@gmail.com

\begin{abstract}
: this study aimed to analyze the meaning of love for the homeland from time to time, the concept of world citizenship, global citizenship, and cosmopolitanism in the global era, and analyze the urgency of patriotism education in the global era. This study used a qualitative method by explaining the feelings and ideas of the informants regarding the occurrence of a specific behaviour or symptom. The meaning of love for the homeland had shifted from ancient times, medieval times, to modern times. In ancient times, love for the homeland was regional; in the Middle Ages, it was personal; while in modern times, it was more national and national. The concepts of global citizenship, global citizenship, and cosmopolitanism in the global era showed connectivity and interdependence between humans in all parts of the world. The urgency of patriotism education in the global era was related to providing learning materials about global citizenship education or global citizenship education to instil awareness of universal humanitarian issues.
\end{abstract}

\begin{abstract}
Abstrak: tujuan penulisan kajian ini yaitu untuk menganalisis makna cinta tanah air dari masa ke masa, konsep kewargaan dunia, kewargaan global, dan kosmopolitanisme di era global, serta menganalisis urgensi pendidikan cinta tanah air di era global. Kajian ini menggunakan metode kualitatif dengan menjelaskan perasaan dan gagasan narasumber terkait terjadinya suatu perilaku atau gejala tertentu. Makna cinta tanah air mengalami pergeseran dari zaman kuno, zaman pertengahan, hingga zaman modern. Cinta tanah air di zaman kuno bersifat kedaerahan, di zaman pertengahan bersifat personal, sedangkan di zaman modern lebih bersifat kebangsaan dan nasional. Konsep kewargaan dunia, kewargaan global, dan kosmopolitanisme di era global menunjukkan adanya konektivitas dan saling ketergantungan antar manusia di seluruh belahan dunia. Urgensi pendidikan cinta tanah air di era global yaitu berkaitan dengan pemberian materi pembelajaran tentang pendidikan kewargaan global atau global citizenship education untuk menanamkan kepedulian terhadap isu-isu kemanusiaan secara universal.
\end{abstract}

\section{PENDAHULUAN}

Cinta tanah air di era global menjadi krusial karena kemajuan teknologi transportasi, komunikasi, dan informasi yang sangat pesat sehingga konektivitas atau keterhubungan umat manusia secara global sangat kuat. Keterikatan dengan daerah-daerah asal semakin berkurang terutama di daerah-daerah perbatasan Indonesia dengan negara-negara tetangga (Bria \& Suharno, 2018). Warga negara (state citizens) atau warga dunia (world citizens) merupakan suatu tegangan yang sangat kuat karena adanya tarik ulur antara lokalitas dan universalitas (Golmohamad, 2009). Hal ini mengakibatkan banyak orang yang memiliki orientasi ke dunia global, baik melalui program internasionalisasi untuk studi, kerja, atau pariwisata. Identitas diri yang melekat pada seseorang dengan wilayah asal menjadi salah satu tuntutan yang harus dipertahankan (Bosio \& Torres, 2019). Warga suatu negara (state 
citizen) dituntut untuk memiliki kecintaan dan kesetiaan pada tanah airnya, sehingga konteks ini membahas tema cinta tanah air yang lebih berkonotasi pada lokalitas.

Dunia menjadi sempit karena adanya koneksi yang dihasilkan oleh kemajuan teknologi informasi. Istilah global village berpandangan bahwa dunia ibarat suatu desa kecil dengan sudut-sudut wilayah yang memiliki koneksi satu sama lain. Hal ini terbukti dengan adanya pandemi Coronavirus Disease 2019 (COVID-19) yang mewabah di seluruh dunia. Dampak dari pandemi COVID-19 dialami oleh seluruh wilayah di dunia, baik dari segi ekonomi maupun sosial. Negara yang menerapkan kebijaksanaan lockdown mengakibatkan ribuan tenaga kerja migran kembali pulang ke negara asalnya, karena tidak dapat bekerja sehingga tidak memiliki penghasilan. Kenyataan ini menunjukkan adanya konsep lokalitas, karena para migran terikat secara yuridis dan menjadi tanggungan dari negara asal bukan negara yang dijadikan sebagai tempat bekerja.

Organisasi negara-negara yang tergabung dalam Asia Pacific Economic Cooperation (APEC) menyoroti masalah nasionalisme vaksin yang dilakukan oleh negara-negara barat dalam forum yang diselenggarakan pada 11 Maret 2021. APEC mempromosikan agar terjadi akses yang adil terhadap pendistribusian vaksin COVID-19. World Health Organization (WHO) sebagai organisasi kesehatan Perserikatan BangsaBangsa (PBB) memiliki keprihatinan yang sama terkait keadilan dalam distribusi vaksin, terutama untuk negara-negara miskin. Penyebab sulitnya negara-negara memproduksi vaksin salah satunya yaitu berkaitan dengan hak kekayaan intelektual atas vaksin COVID-19 yang tidak boleh dilepaskan dari negara-negara penemu vaksin COVID-19. Hal ini mengakibatkan produksi vaksin COVID-19 menjadi lebih lambat, sehingga banyak negara yang tidak memperoleh vaksin tersebut. Fenomena ini menunjukkan bahwa dalam pendistribusian vaksin COVID-19 terdapat tarik ulur antara kepentingan suatu negara, baik secara regional maupun universal terkait aspek kemanusiaan untuk mengatasi batasan antar daerah.

Cinta tanah air relevan dengan era demokrasi karena menekankan pada hak setiap orang untuk berpartisipasi dalam kehidupan bernegara.
Cinta tanah air menjadi suatu kewajiban untuk mencintai negara tanpa syarat (unconditional). Hal ini menunjukkan bahwa cinta tanah air merupakan kewajiban yang didukung dengan adanya sistem demokrasi, sehingga memungkinkan seseorang untuk menentukan pilihannya sendiri dalam melaksanakan kewajiban demokratisnya. Patriotisme dan demokrasi di Amerika sering mengalami tarik ulur, sehingga dapat dijadikan sebagai topik pembahasan yang menarik (Kahne \& Middaugh, 2007). Cinta tanah air di Indonesia cenderung mengarah pada tindakan bela negara. Pemerintah Indonesia mengakui eksistensi orang-orang Indonesia yang berkarya di luar negeri atau diaspora. Diaspora diakui dapat memberikan kontribusi bagi kemajuan negara Indonesia (Alunaza, 2017). Cinta tanah air Indonesia tidak hanya terikat oleh wilayah Negara Kesatuan Republik Indonesia, tetapi orang-orang asli Indonesia yang berada di luar negeri juga dapat mengungkapkan rasa cinta tanah air tersebut.

Sejarah bangsa Indonesia telah menunjukkan pentingnya cinta tanah air dan bela negara, sehingga pemerintah secara turun-temurun telah membuat kebijakan terkait cinta tanah air. Presiden Soekarno mengajak seluruh rakyat Indonesia untuk "berdiri di atas kaki sendiri" dengan slogan "berdikari" agar rakyat mencintai tanah air secara total dan tidak bergantung pada negara lain. Gerakan Cinta Tanah Air (Genta) terjadi pada orde baru, yaitu ketika krisis moneter tahun 1997-1998. Cinta tanah air sampai sekarang terus digemakan, terlebih pada hal-hal yang berkaitan dengan cinta terhadap produk dalam negeri. Pokok bahasan cinta tanah air dan bela negara telah termuat dalam kurikulum pendidikan, khususnya melalui mata pelajaran dan mata kuliah Pendidikan Kewarganegaraan (Wijayanto \& Marzuki, 2018). Berdasarkan uraian di atas, kajian ini membahas beberapa rumusan masalah yaitu (1) makna cinta tanah air dari masa ke masa, (2) konsep kewargaan dunia, kewargaan global, dan kosmopolitanisme di era global, (3) urgensi pendidikan cinta tanah air di era global.

\section{METODE}

Kajian ini menggunakan metode kualitatif dengan menjelaskan perasaan dan gagasan narasumber terkait terjadinya suatu perilaku 
atau gejala tertentu. Kajian secara kualitatif lebih bersifat induktif, sedangkan penelitian kuantitatif lebih bersifat deduktif. Kajian yang bersifat kualitatif berkaitan dengan penalaran di luar proses penalaran yang baku, serta melibatkan ranah etik, politik, dan isu-isu sosial yang berbeda dari ranah personal, interpersonal, dan kontekstual. Data dalam kajian ini dikategorikan sebagai data kepustakaan (library resources), yang bersumber dari artikel dan buku yang memuat gagasan-gagasan narasumber terkait patriotisme, kewarganegaraan, dan pendidikan kewargaan global (global citizenship education). Data dalam penelitian kualitatif dapat diperoleh berdasarkan pendapat-pendapat narasumber, kemudian ditarik kesimpulan yang bersifat umum (Sutton \& Austin, 2015). Data yang telah dikumpulkan kemudian dianalisis secara kritis, dengan menggunakan model pengetahuan alternatif(Morley, 2008). Data dalam kajian ini dianalisis, diseleksi, direduksi, serta disusun secara logis berdasarkan penalaran dan refleksi penulis yang disajikan dalam bentuk teks naratif sehingga mudah dipahami.

\section{HASIL DAN PEMBAHASAN}

\section{Makna Cinta Tanah Air dari Masa ke Masa}

Cinta tanah air mencakup tiga aspek yaitu cinta dengan tempat dan lingkungan, cinta kepada otoritas atau pemerintah sebagai orang yang berwenang mengatur kehidupan bersama, serta cinta pada ide atau cita-cita dan penggunaannya yang membeku dan membaku dalam bentuk nation atau bangsa. Patriotisme atau rasa cinta tanah air diibaratkan sebagai gabungan antara perasaan kesetiaan kucing pada rumah atau tempat yang disukainya, kesetiaan anjing kepada tuannya, serta kesetiaan manusia kepada ide-ide dan penggunaannya (Hayes, 1960). Makna patriotisme semakin berkembang dari zaman ke zaman, mulai dari zaman kuno, abad pertengahan, dan zaman modern.

Cinta tanah air pada zaman kuno lebih diarahkan pada lokalitas yang sempit serta lebih menitikberatkan pada aspek emosional dari orang yang bersangkutan, salah satunya yaitu tempat kelahiran dengan segala hasil dan keindahan wilayah yang mengikat secara emosional seseorang. Kedekatan terhadap suatu tempat dan orang-orang di dalamnya dapat menumbuhkan rasa cinta, bakti, dan kesetiaan pada tempat dan segala sesuatu yang ada di tempat tersebut.
Tanah air tidak dapat diartikan sebagai suatu wilayah yang luas dan abstrak tanpa adanya kedekatan emosional. Kata patria atau tanah air menunjuk pada suatu city atau kota, yang meliputi: (a) wilayah Atena, Sparta, Korintus, dan Smirna serta bukan seluruh kekaisaran Yunani, (b) wilayah Tirus, Sidon, dan Kartago serta bukan seluruh Phoenisia (Robinson \& Alexander, 1951). Patriotisme atau cinta tanah air mengarah pada kecintaan dan kesetiaan terhadap lokalitas yang sangat dekat secara emosional dengan seseorang. Cinta tanah air pada zaman kuno merupakan pengalaman emosional pribadi seseorang pada daerah yang menjadi tempat kelahiran seseorang dengan segala kedekatan tradisi, adat, dan budaya setempat.

Abad pertengahan mencerminkan feodalisme yang ditunjukkan dengan adanya tuan (lord), raja-raja vassal, tuan-tuan tanah, serta kaum bangsawan. Kata feodalisme berasal dari kata feud yang berarti 'tuan' dan dapat bergeser menjadi 'Tuhan'. Cinta tanah air pada abad pertengahan tidak lagi bersifat kedaerahan dan politis, tetapi lebih mengarah pada kesetiaan dan bakti raja-raja vassal kepada kaisar, prajurit kepada raja, atau hamba kepada bangsawan dan tuan-tuannya. Kaisar, raja-raja, bangsawan, dan tuan tanah merupakan orang yang menguasai daerah, tanah, serta hamba-hamba yang menjadi bawahannya. Cinta tanah air pada abad pertengahan ditujukan kepada kaisar, raja, bangsawan, dan tuan-tuan tanah. Pada abad pertengahan sering terjadi perang antar daerah, yaitu antara prajurit yang berperang melawan musuh dari daerah lain. Kesediaan untuk berperang lebih didasari oleh kesetiaan kepada tuan dan raja, bukan pada daerah atau biasa disebut dengan pro domino bukan pro patria (Kantorowicz, 1957). Patriotisme berarti kesetiaan pada raja, tuan tanah, bangsawan, dan pemimpin seperti seekor anjing kepada tuannya.

Zaman modern dipenuhi dengan perkembangan akal budi, ide, dan pemikiran manusia. Rasionalisme berkembang setelah adanya enlightenment atau pencerahan yang ditandai dengan perkembangan ilmu pengetahuan dan teknologi. Kekuatan zaman modern ditunjukkan dengan tumbuhnya subjektivisme manusia karena adanya kesadaran bahwa setiap orang adalah subjek yang bertanggung jawab (Hroch, 2019). Otoritas-otoritas dogmatis di bidang keagamaan hanya dikritisi serta tidak langsung diterima secara turun-temurun. 
Kekuasaan di bidang politik yang bersifat turuntemurun diganti dengan kekuasaan yang dipilih secara rasional melalui pemilihan umum. Hal ini menunjukkan bahwa kekuatan-kekuatan feodal runtuh di zaman modern. Perkembangan di bidang ilmu pengetahuan ditandai dengan adanya metode ilmiah yang menekankan pada pengamatan dan eksperimen, serta penyimpulan yang bersifat deduktif yang mampu mendorong perkembangan teknologi.

Pusat-pusat otoritas yang semula di tangan kaisar, raja, bangsawan, dan pemimpin gereja telah menyebar luas ke berbagai pihak. Slogan liberte, egalite, dan fraternite di Perancis telah menjadi pelopor kebebasan manusia untuk mengembangkan diri dari lingkup kedaerahan dan otoritas kaum feodal. Kesetaraan akan mampu memperkokoh kebebasan, karena dapat menghilangkan ketakutan dari berbagai tekanan dari kekuasaan yang tidak rasional. Kesetaraan dapat menumbuhkan persaudaraan atas dasar berbagai kesamaan yang ada, sehingga mampu melahirkan kesadaran akan nation atau bangsa. Negara Perancis, Jerman, Belanda, Italia, dan Inggris berdiri di Eropa karena adanya gerakangerakan nasional yang berkembang menjadi ideologi nasionalisme (Tridiatno, 1998). Negara atau bangsa berdiri atas dasar ikatan kebangsaan (nation) untuk melepaskan diri dari kekuasaan yang besar dan abstrak.

Nation terbentuk di Eropa melalui proses budaya bersamaan dengan proses politik. Pergeseran dari renaissance ditandai dengan lahirnya ekspresi budaya Romawi dan Yunani kuno, enlightenment (pencerahan), hingga memuncak pada revolusi industri yang berdampak pada proses politik dengan terbentuknya negaranegara bangsa (Hroch, 2019). Peradaban dunia terbentuk dengan mengikuti perkembangan masing-masing negara bangsa serta penjajahan atas benua Asia dan Afrika. Kesadaran baru untuk merdeka dan membentuk nation-state atau negara bangsa yang baru muncul dari penduduk di wilayah Asia dan Afrika. Proses politik yang dipelopori para elit di negara-negara yang terbentuk, kemudian disosialisasikan pada rakyat di negara-negara yang bersangkutan (Kwak, 2013; Conversi, 2007). Kenyataan ini menunjukkan bahwa terdapat banyak nation (bangsa) dan nation-state (negara-bangsa) di Asia, Afrika, dan Amerika Latin.
Objek patriotisme di zaman modern adalah nation atau bangsa. Nation berasal dari kata nasci, natus, atau natio yang berarti komunitas manusia yang terbentuk berdasarkan data kelahiran dan garis keturunan (Maritain, 1951). Data kelahiran tidak hanya diartikan sebagai tanah atau tempat, tanggal kelahiran, dan orang tua saja tetapi juga berarti budaya dan segala aktivitas pemberadaban (civilization) seperti kepercayaan atau agama, sejarah dan perjuangan pada masa lalu, kesenian, serta pendidikan. Kesamaan bahasa dapat menjadi faktor penentu ketika terjadi perdebatan tentang perbatasan dari suatu bangsa, karena bahasa adalah penanda suatu kelompok bangsa (Kedourie, 1960). Bahasa mampu menumbuhkan solidaritas karena merupakan ekspresi lahiriah dari pengalaman batin sebagai pemersatu dari orang-orang yang mempunyai pengalaman yang sama.

Pembentukan suatu bangsa tidak hanya didasarkan pada data kelahiran yang melekat dalam diri setiap individu, tetapi membutuhkan pengakuan secara sadar dari setiap individu. Bangsa-bangsa adalah wujud lahiriah dari keyakinan, kesetiaan, dan solidaritas umat manusia (Gellner, 1983). Unsur pembentuk nation dibagi menjadi dua, yaitu individualitas dan personalitas (Sturzo, 1946). Individualitas berupa fakta fisik dan kultural mencakup sejarah dan tradisi yang membedakan bangsa satu dengan bangsa lain. Personalitas adalah pengakuan secara sadar dari masing-masing individu warga tentang keunikan setiap nation, baik secara kultural maupun non kultural. Personalitas setiap warga dapat membentuk kecintaan, kesetiaan, dan loyalitas kepada nation atau bangsanya (Abi, 2017). Kesetiaan dan loyalitas kepada bangsa biasa disebut dengan istilah patriotisme atau cinta tanah air.

Nation atau bangsa merupakan suatu komunitas abstrak yang tumbuh karena adanya kegiatan dari masyarakat yang tergabung dalam komunitas konkrit. Nation adalah kelompok orang yang secara nyata tinggal bersama serta berelasi dalam bentuk kerja sama atau konflik antara individu satu dengan yang lain (Hroch, 2019). Ikatan setiap individu pada kelompok nation tidak semuanya sama, ada individu yang sangat intensif, sedang, atau dangkal. Nation adalah komunitas yang abstrak karena mewakili keyakinan dan nilai-nilai tertentu, seperti 
budaya mencakup bahasa, seni, dan musik yang menjadi ciri khas dari suatu kelompok. Nation merupakan imagined community atau komunitas yang dibayangkan (Davidov, 2010). Komunitas abstrak dari nilai-nilai kultural ini tidak dibentuk dan dipaksakan dari atas (top down), tetapi tumbuh dari bawah sebagai hasil interaksi warga yang dijalankan oleh kelompok elit tertentu hingga menjadi komunitas abstrak yang dimiliki oleh semua warga.

Nasionalisme merupakan ideologi yang tumbuh pada level komunitas konkrit seperti kegiatan-kegiatan kelompok sosial yang berkaitan dengan kebutuhan materi dan kekuasaan. Nasionalisme merupakan ideologi yang diartikan sebagai suatu gagasan atau cita-cita yang disertai dengan upaya untuk membangun dan mengembangkan bentuk masyarakat tertentu, dalam hal ini nation sebagai komunitas manusia yang konkrit dengan nilai dasar tertentu. Nasionalisme berkaitan dengan kekuasaan dan kesejahteraan materi bagi seluruh warga di suatu bangsa.

Patriotisme adalah rasa cinta, setia, dan bakti kepada nation yang tumbuh pada level komunitas abstrak berupa kegiatan yang berkaitan dengan nilai-nilai budaya. Istilah patriotisme memiliki arti yang sama dengan nasionalisme romantis atau nasionalisme humanis (Hroch, 2019). Patriotisme merupakan purely vegetative groups offeelings atau kumpulan perasaan yang vegetatif (Coleman, dkk., 2018). Patriotisme pada zaman modern sangat dipengaruhi oleh nasionalisme sebagai ideologi. Cinta tanah air berkembang menjadi kecintaan yang eksklusif pada tanah air dalam bentuk bela negara tanpa memperdulikan aspek benar atau salah. Hal ini melahirkan slogan right or wrong is my country, yang sangat provokatif sehingga mendorong semua warga untuk bersedia berperang membela tanah air demi mengalahkan bangsa lain.

Berdasarkan perkembangan arti cinta tanah air atau patriotisme dari zaman kuno ke zaman modern di atas, dapat disimpulkan bahwa patriotisme adalah sentimen, perasaan, dan kekaguman pada tanah air. Patriotisme diwujudkan dalam aksi memuji, hormat, setia, menjaga, dan mempertahankan tanah air ketika dihadapkan pada suatu ancaman. Patriotisme pada dasarnya bersifat defensif bukan agresif (Himes \& Himes, 1993). Objek patriotisme berupa lingkungan atau wilayah fisik yang merupakan tempat seseorang dilahirkan dan dibesarkan, orang-orang yang diberi wewenang untuk mengatur bangsa demi kesejahteraan seluruh warga, serta warga bangsa yang memiliki solidaritas dan saling menyayangi.

Tanah air dapat dibedakan menjadi tiga bentuk, yaitu tanah air real, tanah air formal, dan tanah air mental. Tanah air real adalah bumi tempat orang dilahirkan dan dibesarkan, serta mengalami suka dan duka secara fisik dalam kehidupan sehari-hari. Tanah air formal adalah negara bangsa yang secara yuridis termuat dalam peraturan perundang-undangan yang di dalamnya mengatur hak dan kewajiban, serta mengesahkan atau membatalkan, memberikan perlindungan, dan menghukum seseorang yang bersalah. Tanah air mental tidak bersifat teritorial karena tidak dibatasi oleh ruang dan waktu, tetapi bersifat imajinatif yang dibentuk dan dibina oleh ideologi atau seperangkat gagasan vital.

\section{Konsep Kewargaan Dunia, Kewargaan Global, dan Kosmopolitanisme di Era Global}

Era global adalah zaman tanpa adanya batasan temporal dan spasial, karena proses globalisasi yang mengkombinasikan kekuatan ekonomi, teknologi, sosio-budaya, serta politik. Era global dimulai pada saat kekuatan negara-negara Eropa menjajah Asia, Afrika, dan Amerika (Awdel, Odel, \& Saadi, 2020). Globalisasi dipercepat oleh revolusi pada abad 19, kemudian berkembang pesat di abad 20. Globalisasi didukung oleh aliran teknologi, barang, informasi, gagasan, nilai budaya, jasa, dan manusia yang tidak terbendung (Mao 2014). Manusia di dunia ini saling terkoneksi satu sama lain, yang menyebabkan saling ketergantungan tanpa memperdulikan batasan wilayah, fisik, dan negara. Hal ini lebih dikenal dengan istilah global risk atau resiko global, atau bisa dikatakan bahwa sesuatu yang terjadi di tempat tertentu membawa akibat bagi tempat lain (Mao, 2014). Koneksi menimbulkan suatu relasi agar manusia satu dengan yang lain menjadi lebih dekat, namun di sisi lain manusia juga menjadi lebih sensitif dan rentan. Pandemi COVID-19 telah membuktikan secara nyata bahwa wabah virus dengan mudah dan cepat menjalar di seluruh bumi. Pandemi COVID-19 juga menjadi berkat tersembunyi (blessing in disguise) karena teknologi komunikasi berkembang sangat pesat 
dan memaksa semua orang untuk menggunakan teknologi agar dapat berkomunikasi jarak jauh. Kerja dari rumah, rapat dari rumah, dan macammacam pertemuan dapat dikerjakan dari jarak jauh karena adanya teknologi komunikasi yang membuat manusia satu dengan yang lain saling terhubung dan bergantung.

Patriotisme atau cinta tanah air pada era global seperti sekarang ini memiliki makna yang berbeda dari masa sebelumnya. Kemajuan teknologi telah menghilangkan batasan-batasan spasial dan temporal tertentu di suatu wilayah. Warga Negara Indonesia dapat bekerja dan mendapatkan gaji dari perusahaan asing yang ada di luar negeri. Orang-orang asing dapat tetap tinggal di negara masing-masing, atau bekerja dan mendapatkan gaji dari kekayaan alam di Indonesia. Tanah air adalah seluruh dunia ini, dan sesama warga (compatriot) adalah seluruh warga dunia ini (Altikulac, 2016). Komunitas virtual dalam kehidupan sehari-hari dapat melakukan segala macam aktivitas secara virtual tanpa batasan wilayah, misalnya seperti transaksi barang dan pembayaran. Aktivitas yang bersifat lokal terdapat pada kegiatan-kegiatan pribadi seperti makan, minum, dan tidur yang hanya dapat dilakukan pada lokalitas tertentu. Lingkaran kepedulian dan pengaruh orang-orang dalam komunitas virtual sudah tidak lagi dibatasi oleh dinding-dinding wilayah bangsa dan negara, karena semua bersifat global dan kosmopolitan. Konsep dan gerakan world citizenship (kewargaan dunia), cosmopolitanism (kosmopolitanisme), dan global citizenship (kewargaan global) sangat penting untuk dibahas lebih lanjut.

Kewargaan dunia (world citizenship), kosmopolitanisme (cosmopolitanism), dan kewargaan global (global citizenship) pada dasarnya memiliki makna yang sama, yaitu kewargaan seseorang tidak terikat oleh batasan bangsa (nation) atau negara tertentu tetapi dibatasi oleh komunitas manusia secara luas. Kepedulian dan arah dari ketiga gerakan tersebut yaitu kemanusiaan secara universal tanpa dibatasi oleh bangsa atau negara. Ketiga gerakan tersebut merupakan gerakan moral yang memperjuangkan kesamaan hak semua manusia, menghapus diskriminasi, dan mengembangkan kepekaan pada isu-isu kemanusiaan universal lainnya. Perbedaan ketiga istilah tersebut lebih didasarkan pada konteks dan penekanan yang berbeda.
Istilah world citizenship memiliki arti "dunia" sebagai keseluruhan bumi dan warganya. Istilah cosmopolitanism mengarah pada "dunia" dalam arti cosmos atau alam semesta bukannya "bumi" atau earth. Global citizenship lebih menekankan pada karakter yang mengatasi nasionalitas tertentu. Kata cosmopolitanism secara etimologis berasal dari kata cosmos yang berarti alam semesta dan polites yang berarti warga. Cosmopolitanism berarti paham yang menyatakan bahwa setiap manusia adalah warga dari alam semesta ini. Kosmopolitanisme merupakan pandangan hidup yang mengutamakan tradisi dan budaya manusia secara universal di atas tradisi dan budaya suatu bangsa. Pada dasarnya semua manusia memiliki kepentingan dan nilai-nilai umum atau common interest and values (Gizatova, Ivanova, \& Gedz, 2017). Kontroversi muncul ketika kosmopolitanisme menjadi gerakan politik yang ingin mengurangi pengaruh politik nation-states demi wilayah kemanusiaan yang lebih luas (Martell, 2011). Kosmopolitanisme merupakan gerakan yang ingin menyelesaikan masalah-masalah kemanusiaan di luar batasanbatasan negara bangsa.

Amerika pada tahun 1979 telah membuat panduan kurikulum pendidikan ilmu-ilmu sosial yang menyatakan bahwa tujuan pendidikan ilmu-ilmu sosial adalah mempersiapkan peserta didik untuk menjadi warga yang cerdas, humanis, dan berpartisipasi sebagai warga dunia ( global citizens). Pada tahun 1980-an, khususnya di Amerika dan Britania Raya, berbagai organisasi, perkumpulan tokoh profesional, dan programprogram studi mempunyai upaya serius untuk mengembangkan program bagi generasi muda agar mampu menjadi warga global atau global citizens (Schattle, 2009). Minat pendidikan kewargaan di banyak negara telah bergeser dari pendidikan kewargaan negara (state citizenship) menjadi kewargaan dunia atau global citizenship (Westheimer, 2007). Konsep dan gerakan global citizenship semakin banyak dipakai di samping kosmopolitanisme.

Global citizen adalah pilihan dan cara berpikir, berbeda dengan menjadi warga negara yang terjadi secara kebetulan karena kelahiran. Global citizen berarti memilih untuk peduli kepada isu-isu sosial kemanusiaan umum yang tidak terbatas pada wilayah negara tertentu (Green, 2012). Global citizen memiliki makna peduli pada diri sendiri dan orang lain, dengan kata 
lain berawal dari kepedulian pada diri sendiri dapat membuat seseorang mampu peduli pada yang lain sehingga menumbuhkan rasa peduli kepada sesama secara universal. Global citizen adalah orang yang empati terhadap budaya karena memiliki kompetensi lintas budaya atau intercultural competence, sehingga mampu menghargai budaya yang majemuk. Global citizen adalah orang yang memelihara kemampuan untuk memilih berdasarkan prinsip. Global citizen adalah orang yang bersedia berkontribusi dalam kegiatan sosial politik yang dilakukan oleh suatu komunitas.

Konsep world citizenship, cosmopolitanism, dan global citizenship secara filosofis merujuk pada pendapat filsuf Yunani kuno Socrates ( $\underline{469}$ SM-399 SM) dan Diogenes (412 SM-323 SM). Pada waktu Socrates ditanya oleh seseorang tentang kewargaannya, Socrates tidak menyebut diri sebagai warga Athena tetapi warga dunia (Schattle, 2009). Filsuf Diogenes sebagai pengikut aliran filsafat Cynic mengaku sebagai warga dunia (world citizen) dan menganggap sahabat-sahabatnya yang mengaku sebagai warga Athena adalah munafik (Schattle, 2009). Socrates menganggap kotanya adalah seluruh dunia, sedangkan sahabat, kenalan, dan masyarakatnya adalah seluruh umat manusia. Derek Heater seorang tokoh yang menulis sejarah world citizenship kontemporer menyebutkan bahwa pandangan Sokrates tidak bersifat politis dalam arti membenci Athena, karena Socrates rela dihukum mati sebagai bentuk taat terhadap hukum yang berlaku di Athena. Hal ini menunjukkan bahwa pandangan Socrates merupakan pandangan tentang universalitas manusia.

Paham mengenai istilah warga dunia pada masa Romawi kuno memperoleh pengakuan secara legal dengan adanya gagasan mengenai hukum universal dan keutamaan sipil yang selaras dengan tulisan para pemikir aliran Stoa, seperti Cicero, Marcus Aurelius, dan Seneca. Pemikir Stoa menyatakan bahwa terdapat dua lingkaran sosial manusia, yaitu lingkaran universal yang mencakup seluruh umat manusia dan lingkaran sempit berdasarkan kelahiran manusia. Immanuel Kant berpandangan bahwa manusia di bumi ini menghuni sebuah komunitas universal, yang berkembang ke arah pelanggaran terhadap hak manusiawi. Immanuel Kant mengusulkan adanya cosmopolitan rights atau hak-hak kaum kosmopolitan berdasarkan kemanusiaan universal. Immanuel Kant mampu menginspirasi gerakangerakan kemerdekaan Amerika dan membentuk kelompok republikan di Perancis.

Perang Dunia II yang memuncak pada pengeboman Hiroshima dan Nagasaki, semakin menggemakan wacana tentang kewargaan dunia (world citizenship) bersamaan dengan lahirnya lembaga internasional Perserikatan BangsaBangsa (PBB). Dokumen-dokumen tentang pendirian $\mathrm{PBB}$ memuat penegasan-penegasan tentang pentingnya hak-hak manusia yang didasarkan pada gagasan tentang kewargaan dunia (world citizenship). Lahirnya pernyataan tentang hak-hak manusia (Universal Declaration of Human Rights) pada tanggal 10 Desember 1948 menegaskan bahwa harus ada kesamaan pengakuan hak-hak manusia di atas bumi ini atas dasar kemanusiaan universal.

Kewargaan memiliki syarat yang meliputi tiga hal, yaitu hak (right), tanggung jawab (responsibility). dan kewenangan (authority). Warga dunia adalah mereka yang secara sah menyatakan diri sebagai pribadi yang memiliki kepedulian dan pengaruh pada masalah-masalah global dan mewujudkan pengakuan tersebut dalam tindakan. Masalah global berkaitan dengan bidang tertentu, misalnya seperti lingkungan hidup, perdamaian, jaringan narkoba internasional, perubahan iklim, wabah penyakit, dan bencana. Kewargaan dunia (world citizenship) berbeda dengan warga negara (state citizenship) karena kewargaan negara mengenai seluruh pribadi seseorang, sedangkan kewargaan dunia berkaitan dengan bidang-bidang tertentu saja. Berkaitan dengan otoritas sebagai salah satu unsur dari kewargaan, perlu dibentuk lembaga pemerintahan di tingkat dunia yang mempunyai kewenangan untuk menentukan kebijakan-kebijakan yang sifatnya mendunia.

Perwakilan Komunitas Bahai Internasional pada Konferensi Asia Pasifik tahun 1993, menyatakan bahwa kewargaaan dunia (world citizenship) dimulai dengan pengakuan terhadap kesatuan umat manusia di dunia ini (the oneness of human family) serta koneksi bangsa-bangsa ini di bumi yang dianggap sebagai rumah. Pengakuan atas kesatuan dan koneksi antar bangsa akan menumbuhkan loyalitas manusia pada skopa yang luas, sekaligus memperkuat loyalitas dalam skopa 
yang terbatas. Cinta kepada bangsa atau negara akan diperkuat oleh cinta kepada kemanusiaan secara universal. Cinta tanah air dapat menjadi dasar untuk cinta pada kemanusiaan yang lebih luas. Kosmopolitanisme tidak bersifat elitis, tetapi berakar dari pengalaman orang-orang biasa yang memiliki rasa cinta tanah air dalam arti yang sebenarnya (Horvat, 2020). Patriot kosmopolitan akan menerapkan kepedulian dan cintanya kepada manusia secara universal.

Era global harus mampu menerima konsep dan gerakan kewargaan dunia atau world citizenship, karena merupakan gerakan moral yang menjadi cakrawala bagi gerakan cinta air. Cinta tanah air yang bercorak kebangsaan menjadi perwujudan dari cinta kepada manusia secara universal tanpa batasan negara atau bangsa. Mencintai sebuah negeri tidak menuntut seseorang untuk melupakan keutamaan-keutamaan negeri lainnya, karena seseorang yang berjiwa patriot cenderung menghormati orang yang hidup di negara lain dan negaranya (Ravitch, 2007). Keutamaan atau kesalehan (virtue) adalah disposisi atau kecenderungan tetap untuk selalu berbuat baik yang dimiliki seseorang. Keutamaan ini mendorong seseorang untuk berbuat baik dan memberikan yang terbaik.

Keutamaan adalah sikap yang teguh, pendirian yang kuat, serta kesempurnaan akal budi dan kehendak yang menuntun seseorang untuk melakukan perbuatan yang baik. Orang yang memiliki keutamaan selalu melakukan halhal yang baik dalam segala situasi. Keutamaan manusiawi dapat dimiliki seseorang karena pembiasaan melalui pendidikan formal, informal, atau non formal. Kewajiban untuk mencintai tanah air berdasar pada kenyataan bahwa seseorang mendapatkan identitas budaya dan historis dari tanah air (Aquinas, 1972). Kewajiban untuk menghormati dan mencintai tanah air dibebankan pada setiap individu, karena tanah air telah membentuk seseorang secara kultural dan historis. Tanah air mempunyai peran yang sangat besar bagi pembentukan diri seseorang, sehingga mencintai tanah air merupakan suatu keutamaan. Cinta tanah air merupakan sikap dan disposisi sebagai wadah untuk kebutuhan psikologis manusia. Tanah air dan simbolsimbol seperti bendera dan lagu kebangsaan dapat memberikan kedekatan dan keamanan bagi seseorang (Bader, 2007). Cinta tanah air tidak boleh dipersempit pada individu tertentu saja, tetapi harus mencakup manusia secara keseluruhan.

Cinta tanah air dan loyalitas pada tanah air tidak seperti para penggemar sepak bola yang begitu fanatik. Cinta tanah air bukan sekedar favoritisme pada segala hal yang dimiliki atau milik kelompoknya. Cinta tanah air tidak dimiliki oleh orang yang hanya memuji tanah air tertentu melebihi lainnya (Kleinig, Keller, \& Igor, 2015). Patriotisme harus disertai dengan pengakuan secara sadar dari seorang warga atas tanah airnya. Patriotisme akan membuat seseorang mampu mengakui secara sadar dan menilai secara positif tanah airnya berdasarkan perspektif sendiri. Warga negara harus memiliki kebanggaan atas tanah airnya sehingga mampu dan bersedia untuk mempromosikan atau endorsement atas tanah airnya. Cinta tanah air dapat berupa patriotic dissent yang berupa kritik yang membangun untuk mendorong perbaikan dan kemajuan tanah airnya.

Tindakan yang merupakan salah satu syarat mutlak bagi seseorang yang mencintai tanah airnya yaitu rela berkorban. Pengorbanan dapat berupa kesediaan berperang membela tanah air, menjadi relawan, hingga kesediaan untuk kembali ke tanah air. Tindakan simbolis seperti mengikuti upacara penghormatan bendera dan memberi penghormatan pada lambanglambang negara hanya sebagai ekspresi cinta tanah air, tetapi belum merupakan tindakan nyata cinta tanah air. Tindakan cinta tanah air atau patriotik adalah perbuatan yang berkaitan dengan identifikasi seseorang terhadap tanah airnya (Kleinig, Keller, \& Igor, 2015). Perbuatan sebagai pemenuhan kewajiban-kewajiban komunitas, seperti membayar pajak dan turut serta dalam pemilihan umum tidak termasuk dalam tindakan patriotik.

Pemikir universalis atau moralis liberal tidak memasukkan sikap cinta tanah air atau patriotisme dalam keutamaan atau virtue. Hal ini dikarenakan suatu keutamaan harus berangkat dari netralitas yang tidak memihak sedangkan patriotisme sejak awal sudah memihak tanah air sendiri atas jasa yang telah diberikan (MacIntyre, 2003). Tuntutan mutlak agar cinta tanah air menjadi suatu keutamaan yaitu seseorang tidak boleh mencintai tanah air secara buta (blind patriotism atau pseudo patriotism), tetapi harus konstruktif atau (constructive patriotism). 


\section{Urgensi Pendidikan Cinta Tanah Air di Era Global}

Pendidikan cinta tanah air mendapat perhatian besar dalam kurikulum pendidikan nasional di Indonesia, khususnya pada disiplin ilmu pendidikan kewarganegaraan. Pasal 37 Undang-Undang Nomor 20 Tahun 2003 tentang Sistem Pendidikan Nasional menyatakan bahwa pendidikan kewarganegaraan bertujuan membentuk manusia yang memiliki rasa kebangsaan dan cinta tanah air. Pasal 34 ayat (3) Undang-Undang Nomor 12 Tahun 2012 tentang Pendidikan Tinggi menyatakan bahwa mata kuliah kewarganegaraan, agama, Pancasila, dan bahasa Indonesia memiliki kedudukan sebagai mata kuliah wajib di pendidikan tinggi.

Pendidikan kewarganegaraan di pendidikan tinggi bertujuan mengarahkan mahasiswa agar dapat menjadi warga negara yang memiliki wawasan kebangsaan, serta mampu berpikir kritis, demokratis, dan mencintai tanah air mereka. Pokok-pokok bahasan yang disajikan dalam pendidikan kewarganegaraan yaitu identitas nasional, integrasi nasional, konstitusi, tata hukum nasional, tata pemerintahan, demokrasi, wawasan nusantara, serta hak dan kewajiban warga negara termasuk kewajiban bela negara (Nurwardani dkk., 2016). Materi pembelajaran tersebut sudah cukup untuk membekali mahasiswa agar mampu menjadi warga negara yang memiliki wawasan kebangsaan dan cinta tanah air, terlebih adanya Pancasila yang berkaitan dengan ideologi negara dari segala dimensi.

Pengukuran kualitas patriotisme bangsa Indonesia saat ini perlu dilakukan secara cermat, khususnya para generasi muda yang telah memperoleh pendidikan kewarganegaraan di berbagai jenjang pendidikan. Penilaian negatif terhadap patriotisme generasi muda karena adanya peristiwa tawuran, bullying, intoleransi, dan berita hoax sebagai ekspresi ketidakpuasan terhadap situasi tertentu. Daya kritis dan pembangkangan dari para generasi muda bersifat turun-temurun pada aspek yang berkaitan dengan budaya lokal, mode, dan cara berpakaian (Subaryana, 2012). Hal ini tidak berarti bahwa para generasi muda tidak memiliki rasa cinta tanah air atau patriotisme, tetapi merupakan suatu bentuk ketertarikan generasi muda untuk melakukan perubahan ke arah yang lebih baik (Hartono, 2020). Lembaga Ketahanan Nasional Republik Indonesia menyatakan bahwa indeks ketahanan nasional berada pada status cukup tangguh, sedangkan untuk gatra ideologi dan sosial budaya berada pada posisi kurang tangguh dengan nilai 2,44 dan 2,30.

Berdasarkan fenomena yang telah diuraikan, terdapat dua catatan terkait kurikulum pendidikan kewargaan negara di Indonesia yang dituangkan dalam modul pendidikan kewarganegaraan. Generasi muda perlu dilibatkan dalam setiap kegiatan yang mencerminkan rasa cinta tanah air. Pendidikan kepanduan dan kesukarelawanan sangat relevan untuk diterapkan pada generasi muda (Kleinig, Keller, \& Igor, 2015). Pendidikan kepanduan dan kesukarelawanan salah satunya diwujudkan dalam kegiatan ekstrakurikuler wajib di sekolah-sekolah. Siswa dilatih untuk memberikan pertolongan dalam situasi darurat kebencanaan dalam kegiatan ekstrakurikuler pecinta alam. Keterampilan kesukarelawanan dalam situasi bencana sangat penting untuk dikembangkan, mengingat wilayah Indonesia rawan terhadap bencana. Kegiatan yang berkaitan dengan kebencanaan tidak dapat dilaksanakan tanpa adanya latihan khusus. Hal ini tentu berkaitan dengan konsep cinta tanah air, karena melalui pelatihan khusus para generasi muda dapat mewujudkan rasa cinta tanah air dalam bentuk perbuatan nyata.

Materi pendidikan kewarganegaraan harus diperkaya dengan pokok bahasan tentang Pendidikan Kewargaan Global (PKG) atau global citizenship education, untuk menjawab tantangan-tantangan di era global. Hal ini berkaitan dengan esensi pendidikan kewarganegaraan yang menjelaskan bahwa pendidikan kewarganegaraan dimaksudkan untuk menghadapi dinamika perubahan dalam sistem ketatanegaraan dan pemerintahan, serta tantangan kehidupan berbangsa dan bernegara (Nurwardani, dkk., 2016). Bangsa Indonesia saat ini berada di era global dengan segala tantangan dan resiko yang harus dihadapi, salah satunya yaitu dunia pendidikan yang melaksanakan program kerja sama internasional. Pasal 50 Undang-Undang Nomor 12 Tahun 2012 tentang Pendidikan Tinggi menjelaskan bahwa kesetaraan dan saling menghormati merupakan prinsip untuk melakukan kerja sama internasional. Rencana strategis Kementerian Pendidikan dan Kebudayaan tahun 2020-2024, telah menyebutkan bahwa salah satu profil pelajar Pancasila adalah berkebhinekaan global, yaitu 
sikap memegang teguh budaya lokal dan tetap terbuka pada budaya-budaya lain.

Kerja sama internasional dilakukan melalui beberapa program, diantaranya yaitu pertukaran pelajar dan pengajar, kerja sama dalam menyelenggarakan kegiatan ilmiah di tingkat internasional, atau studi lanjut bagi pengajar di luar negeri. Hal ini selain dimaksudkan untuk meningkatkan eksistensi suatu lembaga pendidikan karena memiliki jaringan di tingkat internasional, juga bertujuan menciptakan kepekaan dan kepedulian pada kemanusiaan global (Green, 2012). Mahasiswa perlu menyadari bahwa setiap individu maupun komunitas harus saling berbagi satu sama lain. Isu-isu yang berkaitan dengan perdamaian, persaudaraan universal, martabat manusia, kemiskinan, keadilan, lingkungan hidup dalam konteks Global Citizenship Education (GCE) atau Pendidikan Kewargaan Global (PKG) perlu dibahas dalam pendidikan kewarganegaraan. Isu-isu tersebut dapat memperluas skopa kepedulian mahasiswa terhadap sesama, sehingga mampu menciptakan keadilan global dan martabat manusia sebagai norma moral yang tidak mengenal batasan.

Dasar filosofis dari world citizenship, cosmopolitanism, dan global citizenship telah menunjukkan bahwa PKG dapat memperkaya aspek-aspek tertentu dalam pendidikan kewarganegaraan. Isu-isu global seperti lingkungan hidup, kemiskinan, keadilan, perdamaian, dan hak asasi manusia banyak dibahas melalui berbagai disiplin ilmu, baik ekonomi, hukum, filsafat, maupun etika (Sutrisno, dkk, 2021). Hal ini mengakibatkan munculnya anggapan tentang ignorance, alienation, dan agnosticism yang berarti rasa tidak peduli, terasing, dan tidak percaya terhadap suatu hal (Golmohamad, 2009). Pembahasan tersebut dinilai tidak cukup jika diterapkan pada generasi muda yang hidup di era global,

PKG dapat memberikan cakrawala yang lebih luas tentang kewargaan, karena pada dasarnya manusia selalu terikat dalam suatu komunitas. PKG dapat menumbuhkan kesadaran manusia untuk menjadi warga dari suatu wilayah yang dibatasi oleh negara dan bangsa, serta menjadi warga seluruh komunitas manusia sedunia. PKG akan mengembangkan kesadaran akan keberagaman (diversity) bangsa dan budaya manusia (Golmohamad, 2009). PKG sangat relevan untuk diterapkan dalam pendidikan di
Indonesia dengan keberagaman suku, bahasa, dan agama yang dimiliki (Rizvi \& Choo, 2020). Kesadaran sebagai satu saudara dalam satu komunitas dapat meminimalisir konflik dan perkelahian mahasiswa yang berasal dari berbagai daerah.

PKG dapat mendorong semangat kesukarelawanan untuk membantu sesama manusia yang membutuhkan pertolongan. Kepekaan untuk berempati terhadap sesama yang semakin berkembang, dapat berujung pada menjadi aksi-aksi solidaritas dalam skopa yang luas. Pendidikan harus membimbing peserta didik agar memiliki kompetensi berpikir kritis dan kemampuan untuk mengembangkan kapasitas diri menjadi pribadi yang mandiri (Merry, 2009). PKG tidak dimaksudkan untuk menyingkirkan pendidikan kewarganegaraan yang telah ada, tetapi lebih dijadikan sebagai suplemen agar pendidikan kewarganegaraan tidak mengarah pada makna patriotisme dalam arti sempit (blind patriotism) yang bertentangan dengan tujuan pendidikan nasional.

\section{SIMPULAN}

Makna cinta tanah air bergeser dari masa ke masa sesuai dengan konteksnya. Cinta tanah air di zaman kuno bersifat kedaerahan untuk membentuk karakter seseorang. Cinta tanah air di zaman pertengahan bersifat personal, yang cenderung diarahkan pada raja, bangsawan, dan tuan tanah. Cinta tanah air di zaman modern lebih bersifat kebangsaan dan nasional. Konsep kewargaan dunia, kewargaan global, dan kosmopolitanisme di era global ditandai dengan adanya konektivitas dan saling ketergantungan antar manusia di seluruh belahan dunia yang menuntut kepedulian antar sesama sebagai saudara dalam komunitas moral universal. Cinta tanah air harus diarahkan pada isu-isu global terkait masalah kemanusiaan secara universal. Urgensi pendidikan cinta tanah air di era global yaitu berkaitan dengan pemberian materi pembelajaran tentang pendidikan kewargaan global atau global citizenship education karena peserta didik saat ini telah banyak berkomunikasi dan berkomunitas di tingkat global. Materi pendidikan kewargaan global dapat menambah wawasan peserta didik mengenai universalitas dan pluralitas bangsa di dunia, sehingga dapat menumbuhkan kepedulian terhadap persoalan kemanusiaan secara universal. 


\section{DAFTAR RUJUKAN}

Abi, A. R. (2017). Paradigma Membangun Generasi Emas Indonesia Tahun 2045. Jurnal Ilmiah Pendidikan Pancasila dan Kewarganegaraan, 2(2), 85-90.

Altikulac, A. (2016). Patriotism and Global Citizenship as Values: A Research on Social Studies Teacher Candidates. Journal of Education and Practice, 7(36), 26-33.

Alunaza, H. (2017). Diaspora sebagai Multi Track Diplomacy Indonesia Guna Mewujudkan Masterplan Percepatan dan Perluasan Pembangunan Ekonomi Indonesia. Jurnal Ilmu Sosial dan Humaniora, 22(2), 72-82. Aquinas, T. (1972). Summa Theologiae. New York: McGraw-Hill.

Awdel, Z. M., Odel, N. M., \& Saadi, W. F. (2020). The Rise of the Globalization and Its Effect on the Autonomy of State and Political Economy. Journal of Critical Reviews, 7(6), 998-1000.

Bader, M. J. (2007). The Psychology of Patriotism. New York: Teachers College Press.

Bosio, E., \& Torres, C. A. (2019). Global Citizenship Education: An Educational Theory of the Common Good? A Conversation with Carlos Alberto Torres. Policy Futures in Education, 17(6), 745-760.

Bria, M. E., \& Suharno. (2018). Pendekatan Kesejahteraan sebagai Strategi Penguatan Nasionalisme Masyarakat di Kawasan Perbatasan. Jurnal Ilmiah Pendidikan Pancasila dan Kewarganegaraan, 3(1), 81-88.

Coleman, M. J., Harris, T. M., Bryant, K. L., \& Reif-Stice, C. (2018). A Cultural Approach to Patriotism. Journal of International and Intercultural Communication, 11(3), 173-191.

Conversi, D. (2007). Democracy, Nationalism and Culture: A Social Critique of Liberal Monoculturalism. Sociology Compass, 2(1), 156-182.

Davidov, E. (2010). Nationalism and Constructive Patriotism: A Longitudinal Test of Comparability in 22 Countries with the ISSP. International Journal of Public Opinion Research, 23(1), 88-103.

Hartono, D. (2020). Fenomena Kesadaran Bela Negara di Era Digital dalam Perspektif Ketahanan Nasional. Jurnal Kajian Lemhannas RI, 41(2020), 15-34.
Gellner, E. (1983). Nations and Nationalism. London: Cornell University Press.

Golmohamad, M. (2009). Education for World Citizenship: Beyond National Allegiance. West Sussex: John Wiley \& Sons.

Gizatova, G., Ivanova, O., \& Gedz, K. (2017). Cosmopolitanism as a Concept and a Social Phenomenon. Journal of History Culture and Art Research, 6(5), 25-30.

Green, M. F. (2012). Global Citizenship-What are We Talking About and Why Does it Matter? Washington DC: NAFSA.

Hayes, C. J. H. (1960). Nationalism: A Religion. New York: Macmillan.

Himes, M. J., \& Himes, K. R. (1993). Fullness of Faith: The Public Significance of Theology. New York: Paulist Press.

Horvat, K. V. (2020). Cosmopolitan Patriotism. Berlin: Springer International Publishing.

Hroch, M. (2019). The Nation as the Cradle of Nationalism and Patriotism. Nations and Nationalism, 26(1), 5-21.

Kahne, J., \& Middaugh, E. (2007). Is Patriotism Good for Democracy?. New York: Teachers College Press.

Kantorowicz, E. H. (1957). The King's Two Bodies. A Study in Medieval Political Theology. Princeton: University Press.

Kedourie, E. (1960). Nationalism. London: Hutchinson University Library.

Kleinig, J., Keller, S., \& Igor, P. (2015). The Ethics of Patriotism a Debate. West Sussex: John Wiley \& Sons.

Kwak, J. (2013). Nationalism and Democracy Revisited the Limits of Democratic Nationalism in South Korea. The Korean Journal of International Studies, 11(1), 143-171.

MacIntyre, A. (2003). Is Patriotism a Virtue. New York: Routledge.

Mao, Z. (2014). Cosmopolitanism and Global Risk: News Framing of the Asian Financial Crisis and the European Debt Crisis. International Journal of Communication, 8(2014), 1029-1048.

Maritain, J. (1951). Man and State. Chicago: Chicago University.

Martell, L. (2011). Cosmopolitanism and Global Politics. Political Quarterly, 82(4), 618-627.

Merry, M. S. (2009). Patriotism, History and the Legitimate Aims of American Education. West Sussex: John Wiley \& Sons. 
Morley, C. (2008). Critical Reflection as a Research Methodology. New York: Nova Science Publishers.

Nurwardani, P., Saksama, H. Y., Kuswanjono, A., Munir, M., Mustansyir, R., Nurdin, E. S., et al. (2016). Pendidikan Pancasila untuk Perguruan Tinggi. Jakarta: Direktorat Jenderal Pembelajaran dan Kemahasiswaan Kementerian Riset, Teknologi, dan Pendidikan Tinggi Republik Indonesia.

Nurwardani, P., Saksama, H. Y., Winataputra, U. S., Budimansyah, D., Sapriya, Winarno, et al. (2016). Pendidikan Kewarganegaraan untuk Perguruan Tinggi: Buku Ajar Mata Kuliah Wajib Umum Pendidikan Kewarganegaraan. Jakarta: Direktorat Jenderal Pembelajaran dan Kemahasiswaan Kementerian Riset, Teknologi, dan Pendidikan Tinggi Republik Indonesia.

Ravitch, D. (2007). Celebrating America. New York: Teachers College Press.

Republik Indonesia. (2003). Undang-Undang Republik Indonesia Nomor 20 Tahun 2003 tentang Sistem Pendidikan Nasional. Lembaran Negara Republik Indonesia Tahun 2003 Nomor 78. Tambahan Lembaran Negara Republik Indonesia Nomor 4301. Republik Indonesia. (2012). Undang-Undang Republik Indonesia Nomor 12 Tahun 2012 tentang Pendidikan Tinggi. Lembaran Negara Republik Indonesia Tahun 2012 Nomor 158. Tambahan Lembaran Negara Republik Indonesia Nomor 5336.

Rizvi, F., \& Choo, S. S. (2020). Education and Cosmopolitanism in Asia: An Introduction.
Asia Pacific Journal of Education, 40(1), 1-9.

Robinson, J., \& Alexander, C. (1951). Ancient History: From Prehistoric Times to the Death of Justinian. New York: Macmillan. Schattle, H. (2009). Global Citizenship in Theory and Practice. New York: Routledge.

Sturzo, D. L. (1946). Nationalism and Internationalism. New York: Roy Publishers.

Subaryana. (2012). The Impact of History Learning to Nationalism and Patriotism Attitudes in the Globalization Era. International Journal of History Education, 13(1), 41-57.

Sutrisno, Sapriya, Komalasari, K., \& Rahmad. (2021). Implementasi Model Pembelajaran Proyek Warga Global dalam Pembelajaran Pendidikan Kewarganegaraan. Jurnal Ilmiah Pendidikan Pancasila dan Kewarganegaraan, 6(1), 155-164.

Sutton, J., \& Austin, Z. (2015). Qualitative Research: Data Collection, Analysis, and Management. The Canadian Journal of Hospital and Pharmacy, 68(3), 226-231.

Tridiatno, Y. A. (1998). Understanding Patriotism in Gaudium et Spes. Manila: Ateneo de Manila University.

Westheimer, J. (2007). Pledging Allegiance: The Politics of Patriotism in America's Schools. New York: Teachers College Press. Wijayanto, R. J., \& Marzuki. (2018). Pendidikan Bela Negara sebagai Tonggak Peradaban Jiwa Patriotisme Generasi Muda. Jurnal Ilmiah Pendidikan Pancasila dan Kewarganegaraan, 3(2), 186-191. 